\title{
Hannah's Ordeal of Childlessness: Interpreting 1 Samuel 1 through the Prism of a Childless African Woman in a Polygynous Family
}

\author{
Alexander I. Abasili (KU, LeUVen)
}

\begin{abstract}
The practice of polygyny (polygamy) is attested to in many parts of Africa. One reason among many for consolidating this practice in some African cultures is the emphasis families place on having male progeny. For many polygamous men, it serves as a way-out of childlessness and "sonlessness." But what becomes of the childless wives in such polygamous marriages? In those patriarchal African societies, where men are at the centre of the stage, the plight of childless or "sonless" wives in a polygamous marriage often goes unnoticed or ignored. By using the childless ordeal of Hannah (1 Sam 1) to mirror the plight of childless women in some polygamous African families, this article highlights the silent sufferings of such childless women and makes a clarion call for an informed and just response to their plight. In addition, it calls attention to the "silent" ordeal of Hannah in 1 Sam 1; an aspect of the text that until now has received very little attention.
\end{abstract}

KEY WORDS: Polygyny, polygamy, Books of Samuel, Hannah, African patriarchy, childlessness.

\section{A INTRODUCTION}

Polygyny (polygamy) is practiced in many parts of Africa. ${ }^{1}$ The emphasis placed on married men having [male] progeny, along with the presence and the deep rootedness of the Islamic religion in many parts of Africa are among the reasons that have consolidated polygyny in Africa. Although the spread and acceptance of Christianity, together with the contemporary economic exigencies and the influence of Western civilization have fostered monogamy in many

* Article submitted: 16 March 2015; accepted: 12 June 2015. To cite: Alexander I. Abasili, "Hannah's Ordeal of Childlessness: Interpreting 1 Samuel 1 through the Prism of a Childless African Woman in a Polygynous Family," Old Testament Essays (New Series) 28 no. 3 (2015): 581-605. $\quad$ DOI: http:// dx.doi.org/10.17159/2312-3621/2015/v28n3a3

1 There are two kinds of polygamy: 1) polygyny (union of a man with more than one wife), and 2) polyandry (a woman married to more than one husband). The latter is almost none existent in Africa. Here we are interested in the former - polygyny. It is also the commonest form of polygamy in the world. See Aylward Shorter, African Culture and the Christian Church (London: Geoffrey Chapman, 1973), 172. 
parts of Africa, polygyny still exists and is well established in much of Africa. ${ }^{2}$ According to recent studies, polygyny, despite its declining tendency, still accounts for about $20-50 \%$ of all marriages in Africa. ${ }^{3}$

Among African Christians and non-Muslims, one of the important roles of polygyny today is the provision of a way-out of childlessness (barrenness) and/or "sonlessness" to a man when his wife is childless. In such a situation, the husband of the childless woman marries another "fruitful" wife and guarantees the continuity of his lineage. But what becomes of the childless wife in such a polygamous marriage? What is the implication and consequence of polygyny for their ordeal of childlessness? By embarking on a contextual reading of 1 Sam 1, this article uses the childless ordeal of Hannah (in both descriptive and prescriptive ways) to mirror the plight of childless women in some polygamous African families. ${ }^{4}$ By seeing things through the eyes of Hannah, this article highlights the "silent" ordeal of Hannah in 1 Sam 1; an aspect of the text that until now has received very little attention. ${ }^{5}$ In addition, by applying the positive contextual implications of this study to an African context, it draws attention to the "silent" plight of barren or childless women in polygamous African families and calls for a just and more informed reaction

2 Charles E. Welch and Paul C. Glick, "The Incidence of Polygamy in Contemporary Africa: A Research Note,” JMF 43/1 (1981): 191-193, 192.

3 Obeng S. Gyimah, "Polygynous Marital Structure and Child Survivorship in SubSaharan Africa: Some Empirical Evidence from Ghana," SSM 68/2 (2009): 334-342, 334.

4 In comparing the plight of Hannah and that of present day married African women in polygamous families, we note that "the similarity between the two will be nonessential but only existential (based on similar life experiences). The great separation in time, space and context between the Hebrew Bible and today's Igbo (African) society does not allow for essential similarity between them." Alexander Izuchukwu Abasili, "Seeing Tamar through the Prism of an African Woman: A Contextual Reading of Genesis 38," OTE 24 (2011): 555-573, 556.

5 Apart from making allusions to Hannah's childless ordeal in passing, only very few works have devoted significant space to her plight and ordeal recorded in 1 Sam 1. In this regard, the work of Chiropafadzo Moyo on Fertility and Curse in the 1 Sam 1 stands out as a good contextual reading of 1 Sam 1-2 vis-à-vis African context. He points out that the understanding of fertility in the HB as a blessing and barrenness as a curse, mirrors the perception of fertility and barrenness in Karanga culture of Zimbabwe. See Chiropafadzo Moyo, "A Karanga Perspective on Fertility and Barrenness as Blessing and Curse in 1 Samuel 1:1-2:10," (D.Th Thesis, Stellenbosh University, 2006). See also Peter D. Miscall, 1 Samuel: A Literary Reading (Bloomington: Indiana University Press, 1986), 10. Rachelle Gilmour, Representing the Past: A Literary Analysis of Narrative Historiography in the Book of Samuel (Leiden: Brill, 2011), 49-50. Yung S. Kim, "The Story of Hannah (1 Sam 1:1-2:11) from a Perspective of Han: The Three-Phase Transformative Process." The Bible and Critical Theory 4/2 (2008): 26.1-26.9 
and attitude to their dilemma. To avoid being too general in referring to the African context, I will use the Igbo culture of Nigeria, West Africa as my main reference point. ${ }^{6}$

One is aware that the pericope of 1 Sam 1, in the larger biblical context, is not just the story of the devout barren woman - Hannah - whose prayer for a son is heard by YHWH. The pericope has a deeper significance. For instance, it inaugurates a decisive era in the history of Israel - the era of Monarchy. ${ }^{7}$ Thus, Samuel eventually became the "king maker" by anointing both Saul and David - the first kings of Israel. In addition, 1 Sam 1 serves as a transition from judgeship to the new era of kingship in Israel. ${ }^{8}$ Although one acknowledges the importance of diachronic readings focusing on these broader significance of the 1 Sam 1 in the HB, this article has opted for synchronic literary reading of the text (1 Sam 1) with emphasis on the silent ordeal of Hannah caused by her childlessness and its significance for women in similar predicament and contexts. In this connection, this article uses narrative criticism as its exegetical method, with particular focus on the point-of-view of Hannah in 1 Sam 1. 9 The choice of methodology is also informed by the narrative character of 1 Sam 1.

For the contextual study of Hannah's ordeal vis-à-vis sonless married African women, I will employ the "Contextual Bible Study" approach developed by the Ujamaa Centre in Pietermaritzburg, South Africa. According to Gerald West:

6 The Igbo people (Ndi-Igbo) are located in Southeastern Nigeria, West-Africa. After the division of Nigeria into 36 states, the Igbo people occupy Anambra, Imo, Enugu, Abia, Ebonyi, part of Delta, Cross-river, Rivers and Akwa Ibom states. See Victor Uchendu, The Igbo of Southeast Nigeria (Chicago: Holt, Rinehart and Winston, 1965), 3. The 2006 Nigerian census places the population of Igbo people at about 21 million. The fact that the majority of the Igbo people are Christians (about $85 \%$ ) who regard the Bible as a sacred text, makes it a suitable socio-cultural point of reference in our study. See Toyin Falola, ed., Igbo History and Society: The Essays of Adiele Afigbo (Trenton, N.J.: African World Press, 2005), 141. 3

7 Andre Caqout and Philipp de Robert, Les Livres de Samuel (CAT 6; Geneva: Labor et Fides, 1994), 36.

8 David Toshio Tsumura, The First Book of Samuel (NICOT; Grand Rapids, Mich.: Eerdmans, 2007), 104.

9 Point-of-view, as used here, is a strand of Narrative Analysis and refers to the various perspectives represented by the various characters in the story. However, this work has opted to highlight the point-of-view of Hannah by seeing the pericope of 1 Sam 1 through her eyes. At various stages of the narrative it asks such questions as: What is Hannah's perspective? How does the narrator depict her and her predicament? According to Fokkelman, "our knowledge of a narrated situation expands if we keep asking whose perspective we are actually being given." Jan Fokkelman, Reading Biblical Narrative: A Practical Guide (trans. I. Smit; Leiden: Deo Publisher, 1999), 139. 
"Contextual Bible study" begins with, but admits to more than, the contextual nature of all interpretation ... It embraces and advocates context. But commitment to rather than cognizance of context is the real concern ... So implicit in the notion of "contextual" as it is used in the phrase "contextual Bible study" is commitment to a particular context, the context of $\ldots$ the marginalized ${ }^{10}$

In other words, Contextual Bible Study lays emphasis on the interpretation of a biblical text for addressing real social-cultural problems in a particular social context. It encourages an exegete (or reader) to critically approach a biblical text from his own context, and advocates the use of the Bible as "a resource, among other resources, for social transformation." ${ }^{11}$ Using Contextual Bible study, I will seek to explore the "ordeal" of Hannah in 1 Sam 1 through the prism of childless African wives in polygynous marriages and highlight the implications thereof in helping such women in today's Africa. In this regard, Hannah's childless ordeal will be examined in a contextual relevant manner to aid women in similar predicament to embrace their situation with courage and look towards the future with hope.

This work is divided into five sections. 1) polygamy and the challenges of childlessness (vv. 1-3); 2) Hannah's affliction in Elkanah's family vis-à-vis the ordeal of a childless married African woman (vv. 4-8); 3) Hannah's prayer to YHWH: a mirror of the prayer of a childless married African woman (vv. 9$20)$; 4) The birth and naming of Samuel vis-à-vis the naming of children in Africa (vv. 20-28); 5) our conclusion: the contextual implications of Hannah's ordeal of childlessness.

\section{B POLYGAMY AND THE CHALLENGES OF CHILDLESSNESS (vv. 1-3)}

The first three verses (vv. 1-3), which describes the initial situation, provides us with the indispensable background information for understanding the entire pericope of 1 Sam 1. In vv. 1-2, the narrator introduces the three main dramatis personae in the pericope of 1 Sam 1 - Elkanah, Hannah and Penninah. Elkanah's significant social status is highlighted by the narrator's mention of his genealogy (to the fourth generation) and his marriage to two wives, Hannah and Penninah. ${ }^{12}$ Even though the laws of Exod 21:10 and Deut 21:15 and the numerous examples of polygamous men in biblical Israel make it clear that polygamy (polygyny) is common in the $\mathrm{HB}$, the reasons for a man taking more

10 Gerald O. West, "Contextuality," in The Blackwell Companion of the Bible and Culture (ed. John F. A. Sawyer; Malden, Mass.: Blackwell Publishing, 2006), 400414, 401.

11 West, "Contextuality," 400-414, 401.

12 Robert P. Gordon, 1 \& 2 Samuel: A Commentary (London: The Paternoster Press, 1999), 72. 
than one wife vary from case to case. ${ }^{13}$ The motive for Elkanah's polygamy may be gleaned from the narrator's introduction of his two wives: "One (אחת) was called Hannah and the second (השנית) Peninnah. Peninnah had children, but Hannah had none" (v. 2). Although both Hannah and Peninnah have the same social status as co-wives of Elkanah, scholars are almost unanimous in their conclusion that the narrator's listing of Hannah's name first is an indication that she is the first wife of Elkanah (v. 2). ${ }^{14}$ In this connection, the term השנית designates first (wife), and second (wife) respectively. ${ }^{15}$ Similar constructions with the first . . . the second . . . are also attested in Gen 4:19; Exod 1:15; Ruth 1:4. ${ }^{16}$

Significantly, the narrator in informing us about the fecundity of Elkanah's wives, reverses the order and places Penninah first (Peninnah has children, but Hannah has none): a subtle way of underlining the grave negative social implications of childlessness for a woman like Hannah living in a cultural context where having an heir is very important. ${ }^{17}$ The childlessness of Hannah prevents "her from contributing to Elkanah's genealogical line. This is in contrast to Elkanah's other wife Peninnah, who has numerous 'sons' and 'daughters"” (1:4). ${ }^{18}$ In this regard, Hannah's childlessness could be taken, not unreasonably, as the motivation for Elkanah's marrying of Peninnah, his second wife. In other words, "because of Hannah's childlessness, she had to share her husband's affection with the depressingly fecund Penninah."19 Childlessness, says Marsman, is one of the commonest reasons for polygamy in the HB. ${ }^{20}$ For men like Elkanah, polygamy offers greater assurance of getting (at least) a

13 In the HB polygamy can also signify a man's high social status. "In addition to Lamech, individuals who engaged in polygamy include prominent men such as Abraham (Gen. 16:3), Esau (Gen. 26:34; 28:9), Jacob (Gen. 29:30), Gideon (Judg. 8:30), Elkanah (1 Sam 1:1-2), David (2 Sam 3:2-5; 5:13), Solomon (1 Kings 11:3), Ahab (2 Kings 10:1), Jehoiachin (2 Kings 24:15), Ashhur (1 Chron. 4:5), Rehoboam (2 Chron. 11:21), Abijah (2 Chron. 13:21), Jehoram (2 Chron. 21:14), and Joash (2 Chron. 24:13)." Andreas J. Kösternberger, God, Marriage, and Family: Rebuilding the Biblical Foundation (Wheaton, Ill.: Crossway Books, 2004), 44. Hennie J. Marsman, Women in Ugarit and Israel: Their Social and Religious Position in the Context of the Ancient Near East (Leiden: Brill, 2003), 141.

14 Ralph W. Klein, 1 Samuel (WBC; Waco, Tex.: Word Books Publisher, 1983), 4.

15 Tsumura, First Book, 108.

16 Tsumura, First Book, 108.

17 Tsumura, First Book, 108.

18 Keith Bodner, 1 Samuel: A Narrative Commentary (Sheffield: Sheffield Phoenix Press, 2009), 12.

19 Bodner, 1 Samuel, 72.

20 The law of Deut 21:15-17 provides legislation in a situation where the two wives in a polygamous family had children. Marsman, Women in Ugarit and Israel, 126. 
son that will keep their names "alive." ${ }^{21}$ Indeed, Elkanah by marrying Penninah bore many sons and daughters which guaranteed the survival of his lineage (v. $4)$.

But what of Hannah? Does she also benefit from this Elkanah's cultural solution to barrenness (polygyny)? As the narrator reveals, Elkanah's marriage to Peninnah only resolves his problem of childlessness but aggravates that of Hannah. ${ }^{22}$ Obviously, since Elkanah is no more childless, he naturally cannot fully understand the deep agony of Hannah's childlessness and thus cannot adequately empathize with her. Thus, Hannah is left alone in her ordeal of childlessness. As Miriam Koktverdgaard notes, "Polygamy is by its very nature, a gender issue . . . and a major aspect of polygamy's gender dimension is the asymmetry it implies." ${ }^{23}$ Polygyny usually serves the sex/gender interest of men. ${ }^{24}$ Thus, many "researchers, and particularly feminist researchers, have typically correlated polygyny with the subjugation of women." ${ }^{25}$ And their conclusion finds support in Hannah's ordeal of childlessness in 1 Sam 1.

Just as in 1 Sam 1 and throughout the $\mathrm{HB}$, polygamy is practiced in many African cultures but in varying degree. As the studies of Hayase and Liaw reveal, the region with the highest level of polygamy in Africa is West Africa (30 to over 50\%), followed by East Africa (20 to 35\%); the region with the lowest level is Southern Africa (less than $20 \%$ ). ${ }^{26}$ In some African cultures, says Shorter, "polygamy serves the prosperity and growth of the extended family and provides status and support for women in societies where they have no vocation other than marriage and the bearing of children to their husband's lineage." ${ }^{27}$ Beyond these benefits of polygamy, there are also numerous disadvantages. According to Kao-Lee Liaw,

From the perspective of individuals, polygamy in sub-Saharan Africa tends to be a rather unstable marriage system, because the obsession with the lineage weakens the conjugal bond. Many

21 Peter R. Ackroyd, The First Book of Samuel (Cambridge: Cambridge University Press, 1971), 19.

22 Joyce G. Baldwin, 1 and 2 Samuel: An Introduction and Commentary (Westmont, Ill.: Inter-varsity Press, 1989), 51.

23 Miriam Koktverdgaard, Polygamy: A Cross-Cultural Analysis (Oxford, N.Y.: Berg, 2008), 126.

${ }^{24}$ Yasuko Hayase and Kao-Lee Liaw, "Factors on Polygamy in Sub-Saharan Africa: Findings Based on the Demographic and Health Surveys," DevEc 35/3 (1997): 293-327, 296.

25 Koktverdgaard, Polygamy, 126.

26 See Hayase and Liaw, "Factors on Polygamy," 293-327, 294.

27 Shorter, African Culture, 173. 
women experience divorces and remarriages through their life courses. ${ }^{28}$ fits. $^{29}$

Indeed, polygamy in Africa is often initiated by men for their own bene-

As in the case of Elkanah, whose polygamy is probably motivated by the childlessness of Hannah, most polygamous marriages in several African contexts are caused by childlessness or "sonlessness" (the search for a male child). In many African cultures, procreation is one of the vital aims of marriage. This African world-view is portrayed in African names such as Kewan (marriage and everything parents do are for the child [a name from Nso tribe of Cameroon]); Nwakaego (a child is greater than any wealth [a name from Igbo culture of Nigeria]), Biadam (a child brings strength to parents [a name from Kassena tribe of Ghana]). In Igbo culture, for instance, even though the mutual support of the spouses remains in many ways an essential goal of marriage, societal and cultural stress is placed on the begetting and training of children. ${ }^{30}$ This is because the perpetuation of lineage is very important to Igbo (and most African) cultures, and marriage is the natural and cultural way of guaranteeing the family lineage. Moreover, it is the duty of children to take care of their parents in old age. In a cultural context without alternative social security for elderly people, such a duty is almost indispensable. In Igbo culture, the marriage bond when sealed with children, becomes almost unbreakable. ${ }^{31}$ In this connection, a childless marriage is termed "unsuccessful" and exposed to many risks like divorce, dispute, and undue cultural pressure. ${ }^{32}$ In such a cultural context, the inability of a married couple to beget biological children is regarded as a calamity that must be immediately resolved.

The idea of "voluntary childlessness" "(often described as living childfree in marriage), seen in some parts of the world in which married couples for

28 Hayase and Liaw, "Factors on Polygamy," 298. See also Bove Riley and Claudia Valeggia, "Polygyny and Women's Health in Sub-Saharan Africa." Social Science and Medicine 68/1 (2009): 21-29, 21.

29 Madipoane Masenya, "Killed by Aids and Buried by Religion: African Female Bodies in Crisis," OTE 19/2 (2006): 492.

30 Hilary O. Okeke, "Population, Marriage, and Family in Nigeria," in Marriage and Family in Nigeria (ed. Benedict E. Etafo and Hilary O. Okeke; Onitsha: Rex Charles \& Patrick Ltd, 1993), 57-76, 65.

31 In the Igbo culture, a fruitful marriage is almost unbreakable. The extended family, in spite of other problems experienced by the spouses, sees such a marriage as fundamentally successful and will do everything in their power to help the marriage succeed. Even when such marriages fail, the children would later (as adults) restore its unity by bringing the parents together.

32 Okeke, "Population," 65. 
various reasons wittingly abstain from having children, may seem strange." 33 Almost every example of childlessness is involuntary and unwanted in the African context. As Masenya rightly observes, the patriarchal African cultures affirm child/son producing wives, "as a married woman, she, of necessity, had to produce male children." 34 In such patriarchal contexts, it is the women who often bear the brunt of childlessness or "sonlessness" and are branded "unfruitful." $" 35$ As a result, they run the risk of either losing their marriage or sharing their husband in a polygamous family with a "fruitful" co-wife. As Aylward Shorter explains, "polygamy is the kindest solution in the case of the first wife's infertility. She would prefer to remain a first wife, rather than be divorced and be faced with the impossible task of finding another husband." This explanation, though reasonable, will not blind us from the "silent" ordeals of childless women in such polygamous marriages. They feel abandoned and neglected in their predicament.

\section{HANNAH'S AFFLICTION IN ELKANAH'S FAMILY VIS- $\grave{A}$-VIS THE ORDEAL OF CHILDLESS MARRIED AFRICAN WOMEN (vv. 4-8)}

Elkanah's annual sacrifice in the Temple of Shiloh (vv. 4-8) serves as a concrete context for revealing how Hannah is treated because of her childlessness. On a positive note, we are told that Elkanah gives to Penninah and her children portions of the flesh of the sacrifice at the sacrificial meal. But to Hannah he gave "one portion for two persons," that is, a double portion because he loved her. ${ }^{37}$ Elkanah's favour to Hannah indicates both his love for her and his attempt to compensate her for her childlessness. Conversely, Peninnah mocks and makes fun of Hannah "because the Lord had closed Hannah's womb" (v. 6). The weight of Penninah's verbal attack on Hannah is highlighted by Karl Friedrich's literal rendering of v. 6: "And her adversary (Penninah) also provoked her with provocation to irritate her." 38 The hip 'il impf. תכעסנה (she

33 Abasili, "Seeing Tamar," 558.

34 Masenya, "Killed by Aids," 493.

35 Okeke, "Population," 72.

36 Shorter, African Culture, 173.

37 The exact meaning of the Hebrew expression אפים is debatable. אפים is a dual noun literarily meaning: two "noses, nostrils" or "face or anger." See BDB, 60. In its present contest, the majority of the English translators render it as "double portion" see NET, NJB, NKJ, EIN. A notable exception is David Tsumura who preferred the literal rendering of אפים as "two noses." See Tsumura, First Book, 113. Karl F. Keil and Franz Delitzsch, Biblical Commentary on the Books of Samuel (Edinburgh: T\&T Clark, 2009), 22. For the meaning of the expression "one portion for two persons," see Danie van Zyl, "Hannah's Share, Once More 1 Samuel 1:5,” OTE 6/3 (1993): 364-339.

38 As used here גם־כעס is a cognate accusative with an emphatic " - גם provoke her severely.” See Keil \& Delitzsch, Biblical Commentary, 111. 
[Penninah] kept provoking her) is used here to express the repeated and aggressive nature of the action. ${ }^{39}$ This malicious taunting of Hannah, which makes her weep and abstain from eating (v. 7), took place not once but "year by year" an expression used three times in the pericope [vv. 3, 7, 8]). Not even her husband's love and kind words ("Hannah ... Why is your heart sad? Am I not more to you than ten sons?" [v. 8]) could assuage the depth of Hannah's sorrow caused by her childlessness in a polygamous family. ${ }^{40}$

Indeed, only Hannah understands the depth of her pain and sorrow. I agree with Mary Evans who stated that, "since Peninnah had many children, including several sons, Hannah's childlessness was to Elkannah little more than a minor inconvenience, one easily overcome by mutual affection (v. 8). But to Hannah it was a personal tragedy." ${ }^{41}$ This is because the most important duty of a married or betrothed woman in the $\mathrm{HB}$ is the begetting of offspring for her husband otherwise she will be viewed as a disgrace. ${ }^{42}$ No wonder Rachel in her childlessness said to Jacob "Give me children, or else I die" (Gen 30:1); a clear expression of her desperation and deep sorrow. Thus, childless women in the HB do everything within their power to resolve their childlessness. ${ }^{43}$

There is also the problem of jealously between co-wives, and the inability of the polygamous men like Elkannah to love their wives impartially (see Gen 21:9-10; Gen 30:14-16; 1 Sam 1:6). ${ }^{44}$ In extreme cases, such as the family of David, conflicts in a polygamous family lead to incest and murder among the progeny (see 2 Sam 13-19). ${ }^{45}$ This explains the unique problems caused by polygamy and the daunting task of keeping such families peaceful and happy. In this regard, Elkannah obviously was not quite successful.

The taunting of Hannah by her co-wife, Penninah resonates with the difficulties endured by childless wives, especially in polygynous marriages. In many African contexts, procreation ranks as the highest duty of a wife. For instance, in the Zimbabwean Karanga culture, a woman's dignity hinges on her ability to procreate. According to Chiropfadzo Moyo, "What is called wife

39 Keil \& Delitzsch Biblical Commentary, 111.

40 Adele Berlin, "Hannah and Her Prayer," Scriptura 87 (2004): 228.

41 Mary J. Evans, 1 and 2 Samuel (NIBCOT; Peabody, Mass.: Hendrickson Publishers, 2000), 15.

42 Kösternberger, God, Marriage, and Family, 41. See also Musa W. Dube, "Grant Me Justice: Female and Male Equality in the New Testament," JRTN 3 (2001): 82$115,88$.

43 The taunting and ridicule of a childless woman like Hannah by her co-wife in a polygamous family is attested three times in the HB - "think of Hagar and Sarah, of Leah and Rachel and here of Penninah and Hannah." Klein, 1 Samuel, 4.

44 Josef Scharbert \& Georg Hentschel, Rut, 1 Samuel, (NEchtB; Würzburg: Echter Verlag, 1994), 31-160, 50.

45 Kösternberger, God, Marriage and Family, 44. 
(mukadzi) among the Karanga people is in fact the uterus. In this culture the purpose of marriage seems that of having children." ${ }^{, 6}$ In such African cultures there is immense cultural pressure on childless women to prove their womanhood. In this sense, childlessness leads to social stigmatization of the victims. For the victims, it is humiliating to be branded "infertile or barren." It is tantamount to saying that such a wife is not a real woman. Even though childless women in both polygamous and monogamous marriages endure this cultural pressure, for cogent reasons, polygyny aggravates this pressure. ${ }^{47}$ Not only is a "fruitful" co-wife (better called rival-wife) of a childless woman in polygyny a constant reminder of her ordeal of childlessness, the taunting, as was the case with Penninah, that sometimes come from the rival-wife adds to her travails. This ridiculing is not unconnected to the jealousy that normally exists between rival-wives in a polygamous marriage. A childless woman in a polygynous family feels the pressure both from within and without. ${ }^{48}$ In addition, her predicament threatens her position as the first wife. As Miriam Koktverdgaard explains:

One of the most salient features of co-wife relations is their internal ranking. ... The wife's ranking typically dictates her specific rights and obligations in the household as well. The commonest way wives are ranked within a household is by order of marriage to their common husband. A wife's rank may also be based on her achievements in the household, or her husband's preferences. ${ }^{49}$

Surely, when a polygynous husband bases the ranking of his wives on achievements (bearing of children), a barren first wife has no chance of retaining her first position among her co-wives. In addition, a childless wife loses the sympathy and full support she should get from her husband. Understandably, with two (or more) wives the husband's attention is divided and it is difficult for him to act impartially in the treatment of his wives. Moreover, since the husband has children through the fruitful wife, the childless woman is alone in her predicament. Surely the difficulties outlined here suggest the benefits of monogamy over polygamy. ${ }^{50}$ Akin to the case of Hannah, a childless wife in such an African context feels isolated in a polygamous family and suffers alone in silence. Naturally, such women ask the why question: Why me? Why my childlessness?

46 Moyo, "Karanga Perspective," 1.

47 Fidelis Nkomazana, "Polygamy and Women within the Cultural Context in Botswana," Scriptura 92 (2006): 265-277, 267.

48 Odukoya Bimbo, Marriages: Real People, Real Problems, Wise Counsel (Lagos: Grace Spring Africa Publishers, 2006), 203.

49 Koktverdgaard, Polygamy, 127.

50 Koktverdgaard, Polygamy, 126. 
In the case of Hannah, why was she childless? Why did YHwH close her womb? Whether we should see in the phrase "because the Lord had closed Hannah's womb" (used twice to describe Hannah's childlessness [see vv. 5, 6]) the divine sanctioning of Hannah's ordeal, is debatable. In the words of Victor Hamilton since procreation in the OT was primarily considered both as a divine commandment and a blessing, barrenness is regarded as "a curse or affliction sent by God. If fertility was one of God's blessings on Israel, how else could barrenness be interpreted?"51

Despite the valuable exegetical insight of Hamilton's assertion, it is only one side of the coin. On the other hand, "there are several instances in the OT where barrenness is not attributed to any form of disobedience. ${ }^{, 52}$ Instead, it serves as part of the divine design to prepare for the birth of an important figure like Samson (Judg 13:5) ${ }^{53}$ To this group belongs Abraham's wife Sarah [Gen 11:30]; Isaac's wife Rebekah [25:21], Jacob's wife Rachel [29:31]. ${ }^{54}$ And Hannah? Does she belong to this group?

There are reasons to answer in the affirmative and scholars are almost unanimous on this. ${ }^{55}$ One immediately notes that the narrator does not accuse Hannah or Elkanah of any sin for which they are punished by YHWH with barrenness. Nonetheless, the narrator consistently describes Hannah as "childless" (" ולחנה אין ילדים - but Hannah had no children" [v. 2]), not as "barren" (עקר) ${ }^{56}$ In this way, the narrator hints at the divine but non-biological nature of Hannah's childlessness.

In explaining the phrase "the Lord had closed Hannah's womb," we observe the narrator's consistent depiction of YHWH as the invisible hand directing the whole situation. To be sure, God is mentioned more than 20 times in the pericope but he never utters a word. He is only portrayed as one who acts and is in control of things. ${ }^{57}$ Therefore God's closing of Hannah's womb is for a purpose. Of course, the immediate implications of this are unpleasant. By closing Hannah's womb, YHWH exposes her to Peninnah's ridicule which makes her weep and abstain from eating; a negative action that makes some feminist readers accuse YHWH of violence against women. ${ }^{58}$ But beyond these negative implications, "the closing of Hannah's womb was in fact God's design

\footnotetext{
51 Victor P. Hamilton, “עקר," NIDOTTE 3:509.

52 Hamilton, NIDOTTE 3:509.

53 Miscall, 1 Samuel, 1.

54 Scharbert \& Hentschel, Rut, 1 Samuel, 49.

55 Scharbert \& Hentschel, Rut, 1 Samuel, 49.

56 This is the root used for designating barrenness in the HB. Hamilton, NIDOTTE 3:510

57 Moyo, "Karanga Perspective," 82-83.

58 Moyo, "Karanga Perspective," 81-82.
} 
to prepare for the birth of an important figure. ${ }^{59,}$ It underlines the miraculous nature of such a conception and YHWH's direct involvement in the birth of the child (Gen 18:10; 30:22). Many commentators are of the view that the narrator is only intent on emphasizing the positive divine plan (the birth of Samuel - a kingmaker and prophet) and not the punishment of innocent Hannah. ${ }^{60}$

But does God not contradict himself by closing Hannah's womb? ${ }^{61}$ In the account of creation (Gen 1:28), God commands human beings to increase and multiply. How can the same God here and in other texts (Gen 16:2) prevent procreation? "Could this be the intention of the God or that of the author?"62 Has the author forgotten so soon the divine command to humanity to increase and multiply? In this regard, many commentators question the trustworthiness of the author in attributing the closing of Hannah's womb to YHWH. "Surely" says Moyo, "there could be other ways that the author would tell the story of mysterious birth, without bringing in the concept of barrenness" complicity in it.

There appears to be no point in continuing this debate, we instead press further the significance of the phrase "the Lord had closed Hannah's womb." The phrase highlights the belief in the pericope (by characters like Hannah) that a child is a gift from YHWH, who has the power to "open" (v. 19) or "close" (vv. 5, 6) the womb (irrespective of whether one is barren or not). ${ }^{65}$ Similar belief is shared by both Sarah and Rachel. Sarah who, though not guilty of any sin, describes her childlessness as "YHWH keeping her from having children" (Gen 16:2). When Rachel's protracted childlessness was over and God enabled her to conceive and bear children, she interprets it as God having "taken away her reproach" (Gen 30:1, 23). It is a similar belief in YHWH's ability to give or withhold the fruit of the womb that motivates Hannah to eventually take her problem of childlessness to YHWH in the Shiloh temple (vv. 9-18).

The conviction in 1 Sam 1 that YHWH grants the fruit of the womb, resonates with the belief in many African societies that children are gifts from God (or gods). This is revealed in certain African names such as Nyemekye (a child is the highest gift to parents from God [a name from the Akan tribe of Ghana]), Chinenyenwa (a child is a gift from God [a name from Igbo land of Nigeria], Wepere (a child is God's gift [a name from Kassena tribe of Ghana]),

\footnotetext{
59 Moyo, "Karanga Perspective," 83.

${ }^{60}$ Scharbert \& Hentschel, Rut, 1 Samuel, 49.

${ }_{61}$ Moyo, "Karanga Perspective," 83.

62 Moyo, "Karanga Perspective," 82.

63 C. Randall Bailey, "The Redemption of YHWH: A Literary Critical Function of the Songs of Hannah and David," BibInt 3/2 (1995): 213-231, 218.

${ }_{64}$ Moyo, "Karanga Perspective," 82-83.

65 See also Marsman, Women in Ugarit and Israel, 142.
} 
etcetera. Since God is the giver of children, it is understandable that childlessness and its solution, in many African contexts, are traced to the divine. In Igbo culture, as Victor Uchendu explains, there is the belief that conception takes place through a combination of three factors: the biological process of sexual intercourse, "the consent of the deities and the willingness of dead lineage members and other friendly spirits to reincarnate themselves. The absence of the latter two agents renders conception impossible." ${ }^{, 66}$ In this connection, some Igbo traditionalists and adherents of African traditional religions perceive childlessness and barrenness as punishments from the fertility gods. As a wayout, "if the childless woman is a traditionalist, she might visit traditional healers and fulfil all the ritual prescriptions and sacrifices suggested by them., ${ }^{, 67}$

The Igbo Christians, however, have a slightly different approach to the divine in relation to fertility. Their belief in God, The-Creator and Giver-ofLife directs them to pray for divine intervention through booking of masses, engaging in novena prayers and visiting "Miracle Centres" and "Men-of-God" (one's choice of approaching the divine depends on his/her Christian denomination). ${ }^{68}$ In addition to asking for a divine miracle, many childless African women nowadays, irrespective of religious affiliation, seek the assistance of orthodox medical practitioners with the conviction that God can also work through them. Unfortunately, not every childless woman can financially afford the full help of orthodox medical doctors. Since the husband (in the face of his wife's barrenness) has the option of polygamy by marrying a "fruitful wife," he easily runs out of patience. In other words, the husband is implicitly blaming the wife for their childlessness or "sonlessness"; "9 "a presumption which is both unjust and often unfounded."70 Definitely, not every case of childlessness can be ascribed to the wife, and only medical examination can identify the reasons for the failure to conceive. ${ }^{71}$ Desperate to avoid divorce or her husband taking a second wife, a childless woman continues the search for a solution to her predicament unabated and often alone. Like Hannah, the depth of such a woman's predicament and agony is really known to her alone, and God is often her last beacon of hope.

\footnotetext{
66 Uchendu, Igbo, 57.

${ }^{67}$ Abasili, "Seeing Tamar," 566. Some of the sacrifices performed in this case are: sacrifices of petition (asking for divine mercy), expiation (asking for forgiveness if either of the couple has sinned), and thanksgiving (expression of appreciation after the birth of the child). See John P. Jordan, Bishop Shanahan of Southern Nigeria (Dublin: Elo Press, 1971), 126.

68 Odukoya, Marriages, 205.

69 Okeke, "Population, Marriage, and Family in Nigeria," 72. See also Abasili, "Seeing Tamar," 567.

70 Abasili, "Seeing Tamar," 567.

71 Abasili, "Seeing Tamar," 567.
} 


\section{HANNAH'S PRAYER TO YHWH: A MIRROR OF THE PRAYER OF A CHILDLESS MARRIED AFRICAN WOMAN (vv. 9-20)}

As the rest of Elkanah's family were eating a sacrificial meal and drinking, Hannah's whole intent is on how to solve her painful problem of childlessness. How does she resolve it? Unlike Rachel who turned to Jacob with the request "give me children, or else I die" (Gen 30:1), or Sarah (whose childlessness caused her to hand over her slave girl [Hagar] to Abraham [Gen 16:2]), Hannah turned to YHWH. "Ironically," says Eslinger, "Hannah is seeking help from the right source. Though Hannah does not know it, YHWH is the one who sealed her womb" [vv. 5, 6]. ${ }^{72}$

The narrator tells us that "Hannah rose (תקום) and presented herself before the Lord [v 9]." The wyqtl of movement - "- ותקום and she arose" (from the root קום), as Robert P. Gordon explains, could refer to "decisive action as well as mere physical movement (e.g. Exod 32:1). ${ }^{, 73}$ In this context, it underlines the decisive nature of Hannah's action geared toward resolving her predicament which involves moving away momentarily from the rest of the family. ${ }^{74}$ Her decision to bring her affliction of childlessness to YHWH, apart from highlighting her deep faith and trust in God, is consistent with the belief in the text that YHWH is the source of fecundity. Since "it is God the giver of life, who has closed her womb, it is only God who can open it.",75

Describing Hannah's mood at this time, the narrator tells us that " $[S]$ he was deeply distressed [והיא מרת נפש] (v. 10a)." Literally, "she was in bitterness of soul" ", 16 a manifestation of an inner anguish. A similar expression is used by Elisha in describing the deep agony of the Shunamite woman after the death of her only son - "for she was in bitter distress" [כי־נפשה מרה־לה] (2 Kgs 4:27). It is, therefore, not surprising that Hannah in her prayer to God "wept bitterly" (v. 10b). In other words, Hannah declares before the Lord the depth of her soul's distress - the yearning for a child.

O Lord of hosts, if only you will look on the misery of your servant, and remember me (וזכרתני), and not forget (ולא־תשכח) your servant, but will give to your servant a male child... (v. 11).

Hannah, apparently long forgotten by YHWH, pleads with him to "remember (זכר) and not forget her" (לא־תשכח). As Tsumura observes, the

72 Lyle M. Eslinger, Kingship of God in Crisis: A Close Reading of 1 Sam 1-12 (Sheffield: Sheffield Academic Press, 1985), 76-77.

73 Gordon, 1 \& 2 Samuel, 74.

74 Tsumura, First Book, 115. See also Elmer A. Martens, "קום," NIDOTTE 3: 902.

75 Evans, 1 and 2 Samuel, 16.

76 See also KJV.

77 Henry Preserved Smith, A Critical and Exegetical Commentary on the Book of Samuel (Edinburgh: T\&T Clark, 1961), 9. 
Hebrew root זכר here "has much stronger nuance than simply putting something into memory; it includes positive actions towards the one 'remembered.",78 Just like YHWH remembered Noah and stopped the rain (Gen 8:1 see also Exod 2:24), so should he remember Hannah and remove her childlessness. At the centre of Hannah's plea is not just a child, but a male child (אנשים זרע). As Herzberg explains, Hannah's request, not just for a child or children but for a son, is totally in accordance with ancient Eastern tradition. Thus, all similar "stories in the Bible which describe the events leading up to the birth of a child are concerned with boy children." 80

Hannah concludes her prayer with a vow - a promise to offer YHWH something or to do something for him, in case he answers her prayer. ${ }^{81} \mathrm{~A}$ vow reveals how earnestly and intensely a person desires a favour from God. ${ }^{82}$ Interestingly, almost all the prayers sealed with a vow in the HB were granted by YHWH (see Gen 28:20-22; Josh 15:16; 1 Sam 14:24). Whoever makes a valid vow is bound to fulfil it (see Lev 27); the only exception is an invalid vow. ${ }^{83}$ According to the Mishnah, "a vow to commit an act in direct violation of halakha is an invalid vow (m. Ned. 2:1)." ${ }^{, 44}$ Hannah in her valid vow, says to YHWH, "If only you . . . give to your servant a male child, then I will set him before you as a Nazarite until the day of his death." It is, however, surprising that Hannah, who had endured childlessness all these years, vows to give back to YHWH the child she prayed for. A comparison with Abraham's action in Gen 22 highlights the unusual nature of Hannah's vow. Here Hannah voluntarily promises to offer back to YHWH her "future" son, but Abraham, who bore Isaac after many years of childlessness, was ordered by YHWH to give him back to him. ${ }^{85}$ The common denominator between Hannah and Abraham is their strong faith in YHWH. ${ }^{86}$ Thus, Hannah's vow is not without some implica-

78 Tsumura, First Book, 118.

79 The expression זרע אנשים (lit. seed of men) is ambiguous. Nonetheless, majority of scholars translate it as a male child. For instance, Hans Wilhelm Hertzberg, 1 \& II Samuel: A Commentary (London: SCM Press, 1964), 25. NET (New English Translation) - "a male child"; NJB (New Jerusalem Bible) - "a boy"; NKJV - "a male child"; EIN (Einheitsübersetzung) - "einen männlichen Nachkommen"; LEE (Isaac Leeser [Jewish Bible]) - "Man-child." Nonetheless, Michael Carasik has a different opinion. He argues that the "phrase in 1 Sam 1:11 can be interpreted conclusively as Hannah's profound prayer to be blessed with a mortal offspring." See Michael Carasik, "Why Did Hannah Ask for 'Seed of Men'?” JBL 129/3 (2010): 435.

${ }^{80}$ Hertzberg, 1 \& II Samuel, 25.

81 Smith, Samuel, 9.

82 Smith, Samuel, 9.

83 Jephthah actually sacrificed his daughter. See Moshe Reiss, "Jephtha's Daughter," JBQ 37 (2009): 57-63, 59.

${ }^{84}$ Cited in Moshe Reiss, "Jephtha's Daughter," 59.

85 Tsumura, First Book, 118.

86 Tsumura, First Book, 118. 
tions. The uniqueness of Hannah's vow, apart from expressing her gratefulness to YHWH, reveals her heart's sole desire - to bear a son (an heir) and become a mother. Whether the child stays with her or not is secondary. It is as if she said to YHWH, "just give me a son (through which I become a mother) and I give him back to you."

Hannah's ardent desire to just become a mother parallels the craving of many childless African women for motherhood. In many African contexts, motherhood is not only deeply appreciated but has far reaching social implications for married women. As Ikenga Metuh explains:

Motherhood is a much sought after status in most African societies. It is the dream and self-fulfillment of every African young woman. A woman who cannot or has not given birth is a social misfit. If she has never conceived she is openly ridiculed and told that she is not a woman. ${ }^{87}$

In such an African context, a woman who has conceived but suffers a miscarriage is better than one who never conceived at all. According to Yasuko Hayasa, in such a culture "sterility is not only undesirable but also evil." 88 In other words, sterility or barrenness (the inability of a woman to become pregnant) is treated with greater aversion than childlessness. Thus, a man married to a barren woman does not waste much time in finding a solution in either polygamy or divorce. ${ }^{89}$ But a woman who suffers miscarriage, although still childless, is "fertile" and has a realistic hope of "successfully" bearing a child. In the face of childlessness, it is vital that a woman at least shows that she is fecund and normal. ${ }^{90}$ It is for this reason that some women go as far as feigning pregnancy or secretly adopting a child. In a culture that regards adoption as importing a "foreigner" into the lineage, it is common for such barren women to pretend that an adopted child is their biological child. ${ }^{91}$ Despite the use of these deceptive means to showcase her fecundity, the childless woman knows that conceiving and bearing a child is the best way-out of her predicament. Whether the child stays with her or not is a secondary consideration. What is important is to become a mother. It is from this perspective that a childless African woman, in a similar context, will understand Hannah's vow in the temple to hand back her "prayed-for son" to YHWH.

87 Emefie Ikenga Metuh, Comparative Studies of African Religions (Enugu: Snaap Press, 1999), 188.

88 Hayase and Liaw, "Factors on Polygamy," 295.

89 Hayase and Liaw, "Factors on Polygamy," 296,

90 Metuh, Comparative Studies, 188.

91 Emmanuel Uwalaka, Towards a Sustainable Happy Marriage: A Functional Approach (Owerri: Danstarling, 2008), 99. 
As Hannah was pouring out her heart in prayer to YHWH, Eli the highpriest mistook her for a drunken woman: "How long will you make a drunken spectacle of yourself? Put away your wine" (v. 14). Ironically, Hannah who till now neither ate nor drank anything is here accused of drunkenness. However, since drinking of wine, sometimes to the extent of getting drunk, is a frequent concomitant of sacrificial meals, Eli's assumption is unsurprising. ${ }^{92}$ The readiness with which Hannah responded to the accusation also confirms this fact: "No, my lord . . . I have drunk neither wine nor strong drink. Do not regard your servant as a worthless woman (בת־בליעל), for I have been speaking out of my great anxiety and vexation all this time" (vv. 15, 16). The תבבליעל (daughter of beliya'al) - is a vague but very negative OT expression used for depicting people showing strange or evil tendencies (akin to the prince of evil - Belial in 2 Cor $6: 15) \cdot{ }^{93}$ In other words, Hannah's prayer was very intense, passionate and emotional (causing Eli to mistake her for a drunkard and worthless woman). In this way, the narrator offers us an aperture into the depth of Hannah's inner agony which she pours out before YHWH. Her "drunkenness" is not caused by wine but by grief of childlessness (v. 15). Eli then bids Hannah farewell with the prayer that YHWH will grant her heart's desire. Eli's prayer here recalls the priestly prayer of Num $6: 24-26$, “. . . the Lord make his face to shine upon you, and be gracious to you." The obvious contrast in Hannah's attitude before (she was sad, without appetite for food [v. 7]) and after her prayer (she ate, drank and was happy [v. 18]) reveals her conviction that YHWH has heard her prayer and remembered her. ${ }^{94}$ This not only confirms her deep faith in God's ability to "open" and "close" the womb, but her anticipated joy of motherhood.

\section{E THE BIRTH AND NAMING OF SAMUEL VIS-À-VIS THE NAMING OF CHILDREN IN AFRICA (vv. 19-28)}

In two verses, the narrator succinctly reports that "Elkanah knew (ידע) his wife Hannah, and God remembered her (ויזכרה יהוה)." ויזכרה יהוה The phrase from implying YHWH's "fulfillment" of his promise, ${ }^{96}$ also stresses the personal note of the divine favour: he did it for her (Hannah) - not for them (Hannah and Elkanah). This agrees with the narrator's steady depiction of Hannah's childlessness as a personal tragedy. Hence, Hannah is consistently portrayed as "lonely" in her family - she prays, makes vow, rejoices alone. ${ }^{97}$ She is ironically lonely in the midst of her family.

\footnotetext{
92 Smith, Samuel, 10.

93 Gordon, 1 \& 2 Samuel, 75. See also Tsumura, First Book, 123-124.

94 Baldwin, 1 and 2 Samuel, 53.

95 See also Gen 8:1 and Exod 2:24.

96 Tsumura, First Book, 127.

97 Moyo, "Karanga Perspective," 29.
} 
We note that Hannah's conception of a child (v. 20a) signals her change of status and debunks the assumption of Penninah that she is barren. ${ }^{98}$ In the $\mathrm{HB}$, "the mere fact that a wife is pregnant raises her status considerably (see Gen 16:4)." 99 In naming the child, Hannah called him Samuel, for she said, "I have asked him of the Lord" (v. 20b, see also v. 27]. ${ }^{100}$ This "parenthetic-note" is significant. Without referring to the etymology of the name Samuel, it underlines and immortalizes the circumstances surrounding the birth of the boy Samuel. Tsumura's studies have clarified the various etymological ways of explaining the name שמואל by different authors: "(a) Semuael 'Heard-of-God,' (b) Seme'el 'He-who-is-from-God,' (c) Simuhu-'il 'His-name-is-El,' (d) Semuel 'Name-of-God.",101 Interestingly, majority of the etymological explanation of שמואל points to the divine origin of the child. He is a "God-given Child." similar example of a child's name pointing to the circumstances of his birth is attested in 1 Sam 4:21, where the son born by the wife of Phinehas was named Ich'abod, meaning, "The glory has departed from Israel!" (1 Sam 4:21).

The narrator tells us in vv. 24-28 that Hannah fulfils her vow and sends Samuel to the temple at Shiloh where she handed him over to Eli, the high priest. Interestingly, the story which began with the announcement that Hannah has no child, ends with her offering her hard earned child to God. Both at the beginning and the end of the pericope (1 Sam 1), she is without a child. The difference is that she is now the mother of a son, which means more to Hannah than any other thing.

There is little doubt that a married childless African woman in a similar predicament would dream of having her problem resolved like that of Hannah. She not only gives birth to a child (which makes her a mother) but a son. In some African contexts, "sonlessness" is almost treated like childlessness. In such a patrilineal society, "women with female children but without a male suffers, to a large extent, the plight of a childless woman." a child, irrespective of gender, makes a woman a mother, only a male child is an heir. Therefore, in terms of lineage perpetuation in Igbo land, "a marriage not blessed with a male child is to the family a childless marriage."104 There are a number of cultural reasons for this practice. Igbo society is patriarchal and

98 Moyo, "Karanga Perspective," 127.

99 Hertzberg, I \& II Samuel, 25.

100 Some commentators have fingered this parenthetic note "I have asked him of the Lord" as suggesting the name Saul from the Hebrew sa'al - to ask - is implied because the incidence originally refers to the birth of Saul. See Baldwin, 1 and 2 Samuel, 53.

101 Tsumura, First Book, 128.

102 Tsumura, First Book, 128.

103 Abasili, "Seeing Tamar," 562.

104 Innocent V. O. Modo, "A Cultural Panacea to the Problem of 'Malelessness' in Igbo Land of Nigeria: The Study of Eze-Chiman Clan," AAnt 5 (1999): 198. 
lineage is only traced through the father (a male). Thus, only a male child can perpetuate the family name and lineage. It is also the duty of a male child to ensure his father's befitting burial and pave the way for him to be received into the prestigious group of "family ancestors." has the right of property inheritance from his father, otherwise his father's property will be inherited by another male next-of-kin. ${ }^{106}$ To the parents, having a male child has a social prestige attached to it. Notwithstanding the merits of these explanations in helping us understand the cultural logic behind "male preference," they cannot remove the inherent injustice and discrimination in denying an Igbo female child the right of inheritance, an action tantamount to making her a second class citizen in her father's house. ${ }^{107}$ Justice demands that every child should be treated equally irrespective of its gender. As a result of this unfair situation, no married Igbo woman wants to have only female children. Like Hannah, a childless Igbo woman would not only request a child, but specifically for a male child. ${ }^{108}$ The birth of such a son wipes away all her tears and remains indelible in her life.

It is understandable that a childlike Samuel, born after many years of childlessness, is deeply appreciated in such patriarchal cultures such as Igbo land. Such children symbolize the liberation and joy of their mothers, and the success of their parents' marriage. It is fitting that the circumstances of their birth are reflected in the names given to them. ${ }^{109}$ In Igbo culture,

the names a child receives are expressive of the circumstances surrounding his/her birth, appearance, character, history, the parent's concern for the future of the child, or the parent's status or worldview. ${ }^{110}$

After many years of prayerfully longing for a child, a son born to a childless woman in a polygynous Igbo family may be named Amarachukwu (a sign of God's grace to the parents) or Onyinyechukwu (God's gift to the parents) or Nchetachukwu (God has remembered me) or Ogbogu (one who restores [family] peace). These names are the result of the contexts within

105 Alexander I. Abasili, Resolving the Dilemmas of Life: Way out When There Seems to Be No Help and Hope (Enugu: Snaap Press, 2004), 54.

106 Ben Okwu Eboh, "Feminism and African Cultural Heritage," JIT 5/2 (2003): 134.

107 Alexander I. Abasili, "The Understanding of Adultery in the Hebrew Bible and in Igbo Culture" (Doctoral Dissertation, Katholieke Universiteit Leuven, 2012), 269.

108 Odukoya, Marriages, 203.

109 Edmund Ilogu, Christian Ethics in an African Background: A Study of the Interaction of Christianity and Ibo Culture (Leiden: Brill, 1974), 45.

110 Alexander Abasili, "The Meaning and the Implication of the Name 'Sons of Mary Mother of Mercy' for Each Member of the Sons Congregation," in Sons at 40: Looking at the History, Challenges and Hopes for the Future (ed. by Paulinus Iwuji \& Alexander Abasili; Owerri: Edu Edy, 2010), 43-57, 43. 
which such a child is born and a means of thanking God for his benevolence. ${ }^{111}$ It is in this connection, that a childless Igbo woman would understand Hannah's choice of the name Samuel for his son because "she has asked for him of the Lord."

\section{F CONCLUSION: THE CONTEXTUAL IMPLICATIONS OF HANNAH'S ORDEAL OF CHILDLESSNESS}

Our study of Hannah's ordeal of childlessness reveals some positive contextual implications for childless (or barren) African women and for childless women in similar polygamous families in particular.

\section{Silent Suffering of Childless (or Barren) Women in Patriarchal Polygynous Families}

Based on our reading, there are reasons to conclude that Hannah was Elkanah's first wife and that he really loved her. But because of her childlessness, Elkanah married the "fruitful" Penninah (fittingly described by some authors as Hannah's tormentor) who bore him both male and female children. Even though polygamy resolved Elkanah's dilemma of childlessness, it created more problems for Hannah. Apart from her burden of childlessness, she had to endure her rival-wife's incessant taunting. Although her husband Elkanah loved her, his attention was divided as he also had to cater for Penninah and her children. Moreover, the fact that Elkanah was not childless added to Hannah's loneliness in her predicament. Put differently, despite the large size of Elkanah's family, Hannah in her childlessness was lonely and almost isolated.

The ordeal of Hannah in Elkanah's polygamous family parallels that of many childless women in similar African contexts. On the one hand, they are under immense cultural pressure because their womanhood and their marriage success are defined by their "fruitfulness." On the other hand, they are internally confronted by their "rival-wives" incessant verbal attacks. Moreover, seeing the children of their co-wives is a constant reminder of their own childlessness. So both within and outside the family, they are under siege due to the agony of childlessness. In this connection, Eli's accusation of Hannah of being drunk is understandable. Hannah was drunk not with wine but with grief (v. 14).

Hannah's agony of childlessness in patriarchal Hebrew society resonates with the agony of women in similar predicaments in some African cultures. The agony of such women questions the fairness of defining a woman's marital success by her fecundity. By implication, "[I]t reduces married women to child producing machines. But Married women are valuable for who they are, not

111 Themba Moyo, "Naming Practices in Colonial and Post-Colonial Malawi," Inkanyiso 4/1 (2012): 10-16, 10. 
merely for their procreative function. $" 112$ In the same vein, child bearing should not be used as a yardstick for defining a successful marriage in patriarchal African societies. It is reductionist, unfair and unacceptable.

\section{Polygyny as a Solution to Childlessness or Barrenness is Questionable}

The ugly experiences of Hannah in the polygynous family of Elkanah highlight the negative role of polygyny in aggravating the sufferings of childless (or barren) women in patriarchal society. By its very nature, polygyny (polygamy) is a gender/sex issue. ${ }^{13}$ It favours male gender and disadvantages the female. Clearly, from a childless woman's perspective, polygyny as a solution to childlessness is questionable and unacceptable. It provides a lopsided cultural solution to childlessness in patriarchal societies. Polygyny solves the childless problem of the male gender but only aggravates the childless woman's suffering and agony. Since the husband of such a woman is not childless, he naturally cannot fully understand the deep agony of his wife's childlessness and thus cannot adequately empathize with her. Thus, men like Elkanah who resolve their childlessness through polygamy are prevented from grasping the depth of their wife's agony of childlessness. Against this backdrop, it is not unreasonable to say that Hannah's situation would have been slightly better in a monogamous family because the burden of childlessness will be carried equally by the "childless couple" and she may not feel as lonely and isolated.

From the foregoing, the odds are against polygamy offering a just solution to childlessness. Certainly justice and fairness demand that an involuntary childless couple should look for an inclusive solution to their problem of childlessness. In this connection, childless couples in a patriarchal African society, apart from standing together in their predicament, are reminded that companionship and mutual assistance are vital aspects of marriage and should be appreciated. Undoubtedly, "even without children (resulting from causes beyond a couple's control), the companionship of married couples rooted in love constitutes enough grounds for happy married life."114 In addition to remaining together, involuntary childless couples can tap into their faith in God to assist them in their predicament. Hannah, by going to God in Shiloh, was consoled and her childlessness was resolved. Hannah is, therefore, a good example of the positive role of faith in God in consoling a childless woman and in resolving the ordeal of involuntary childlessness.

Moreover, adopting a child seems a very good option for resolving involuntary childlessness. According to John Paul II, barrenness or "[P]hysical sterility can be for spouses the occasion for other important services to the life

\footnotetext{
12 Abasili, "Seeing Tamar," 569.

113 Koktverdgaard, Polygamy, 125.

114 Koktverdgaard, Polygamy, 569.
} 
of the human person, for example, adoption." 115 Hence, despite the branding of adoption as an importation of a "foreigner" into the lineage in some African societies, it remains a viable solution to involuntary childlessness and barrenness. Moreover, "research has shown that, apart from biologically bearing one's children, adoption is the second viable alternative to becoming parents." 116 Surely, compared to divorce and polygyny, adoption is a better and more just solution to involuntary childlessness in those contexts where childlessness is a tragedy.

\section{The Preference for Male Children is Questionable}

Hannah, in her prayer for a child, requested not just for a child but for a male child (זרע אנשים [v. 11]); a request which is informed by the patriarchal nature of Hebrew biblical culture and its emphasis on a man having an heir. For those childless African women living in contexts where "sonlessness" is almost treated as childlessness, Hannah's request for a son is understandable. In Igbo land, for instance, only a male child has the right to inherit the parents' assets. Moreover, the patriarchal Igbo culture permits that only the male child is capable of perpetuating his father's lineage. For these reasons having a male child is a sine qua non. It is also the duty of a male child, among the traditionalists, to ensure a fitting burial for his father and pave the way for his reception into the prestigious group of "family ancestors." having a male child has a social prestige attached to it. Despite the value of these explanations in clarifying the role of a male child in such a patriarchal society, they cannot excuse the unjust treatment of female child in those contexts.

Certainly such a lop-sided preference for a male child or children and discrimination against a girl child or children is unfair and unacceptable. Such discriminatory treatment of the girl child is rejected in Article 1 of the United Nations Universal Declaration of Human Rights which states that, "all human beings are born free and equal in dignity and rights." 118 Hence, the practice in some African contexts today of giving preference to the male child or children with regard to expectations, rights, rewards, duties and obligations is not acceptable. This is a clear case of discrimination against women for an ulterior motive. Such an action is against the UN Convention on the Elimination of All Forms of Discrimination against Women of December 1979. Justice demands

115 John Paul II, Apostolic Exhortation Familiaris Consortio (November 22, 1981, no 14).

116 Brent Waters, Ethics and Technology: Towards a Theology of Procreative Stewardship (Wiltshire: Longman, 2001), 70. See also Abasili, "Seeing Tamar," 572.

117 Abasili, Resolving, 54.

118 Article 1 of United Nations Universal Declaration of Human Rights of December 10, 1948. Online: http://www.un.org/en/universal-declaration-human-rights/index .html (accessed on 04.07.2015). 
that there should be no special privileges in the appreciation or treatment of either male or female children. Every child is equal and should be recognized as such and culture or tradition should not be used as reason for altering this gender equality.

\section{BIBLIOGRAPHY}

Abasili, Alexander I. Resolving the Dilemmas of Life: Way out When There Seems to Be No Help and Hope. Enugu: Snaap Press, 2004. . "Seeing Tamar through the Prism of an African Woman: A Contextual Reading of Genesis 38." Old Testament Essays 24/3 (2011): 555-573. . "The Understanding of Adultery in the Hebrew Bible and in Igbo Culture." D.Th. Thesis, Katholieke Universiteit Leuven, 2012. . "The Meaning and the Implication of the Name 'Sons of Mary Mother of Mercy' for Each Member of the Sons Congregation." Pages 43-57 in Sons at 40: Looking at the History, Challenges and Hopes for the Future. Edited by Paulinus Iwuji and Alexander Abasili. Owerri: Edu Edy, 2010.

Ackroyd, Peter R. The First Book of Samuel. Cambridge: Cambridge University Press, 1971.

Bailey, Randall C. "The Redemption of YнwH: A Literary Critical Function of the Songs of Hannah and David." Biblical Interpretation: A Journal of Contemporary Approaches 3/2 (1995): 213-231.

Baldwin, Joyce G. 1 and 2 Samuel: An Introduction and Commentary. Westmont, Ill.: Inter-varsity Press, 1989.

Berlin, Adele. "Hannah and her Prayer." Scriptura 87 (2004): 227-232.

Bodner, Keith. 1 Samuel: A Narrative Commentary. Sheffield: Sheffield Phoenix Press, 2009.

Brown, Francis, Samuel R. Driver and Charles A. Briggs. A Hebrew and English Lexicon of the Old Testament (Reprinted from 1906 edition). Peabody, Massachussets: Henrickson, 2006.

Caqout, Andre and Philipp de Robert, Les Livres de Samuel. Commentaire de l'Ancien Testament 6. Geneva: Labor et Fides, 1994.

Carasik, Michael. "Why Did Hannah Ask for 'Seed of Men'?” Journal of Biblical Literature 129/3 (2010): 433-36.

Dube, Musa W. "Grant Me Justice: Female and Male Equality in the New Testament." Journal of Religion \& Theology in Namibia 3 (2001): 82-115.

Eboh, Ben Okwu. "Feminism and African Cultural Heritage." Journal of Inculturation Theology 5/2 (2003): 123-140.

Eslinger, Lyle M. Kingship of God in Crisis: A Close Reading of 1 Sam 1-12. Sheffield: Sheffield Academic Press, 1985.

Evans, Mary J. 1 and 2 Samuel. New International Biblical Commentary. Peabody, Mass.: Hendrickson Publishers, 2000.

Falola, Toyin, ed. Igbo History and Society: The Essays of Adiele Afigbo. Trenton, N.J.: African World Press, 2005.

Fokkelman, Jan. Reading Biblical Narrative: A Practical Guide. Translated by Ineke Smit. Leiden: Deo Publisher, 1999.

Gilmour, Rachelle. Representing the Past: A Literary Analysis of Narrative Historiography in the Book of Samuel. Leiden: Brill, 2011. 
604 Abasili, "Hannah's Ordeal," OTE 28/3 (2015): 581-605

Gordon, Robert P. 1 \& 2 Samuel: A Commentary. London: The Paternoster Press, 1999.

Gyimah, Obeng S. "Polygynous Marital Structure and Child Survivorship in SubSaharan Africa: Some Empirical Evidence from Ghana." Social Science and Medicine 68/2 (2009): 334-342.

Hayase, Yasuko and Kao-Lee Liaw. "Factors on Polygamy in Sub-Saharan Africa: Findings Based on the Demographic and Health Surveys." The Developing Economies 35/3 (1997): 293-327.

Hertzberg, Hans Wilhelm. 1 \& II Samuel: A Commentary. London: SCM Press, 1964.

Ilogu, Edmund. Christian Ethics in an African Background: A Study of the Interaction of Christianity and Ibo Culture. Leiden: Brill, 1974.

John Paul II. Apostolic Exhortation Familiaris Consortio. November 22, 1981, no 14.

Jordan, John P. Bishop Shanahan of Southern Nigeria. Dublin: Elo Press, 1971.

Keil, Karl F. and Franz Delitzsch. Biblical Commentary on the Books of Samuel. Edinburgh: T\&T Clark, 2009.

Kim, Yung S. "The Story of Hannah (1 Sam 1:1-2:11) from a Perspective of Han: The Three-Phase Transformative Process." The Bible and Critical Theory 4/2 (2008): 26.1-26.9.

Klein, Ralph W. 1 Samuel. Word Biblical Commentary. Waco, Tex.: Word Books Publisher, 1983.

Koktverdgaard, Miriam. Polygamy: A Cross-Cultural Analysis. Oxford, N.Y.: Berg, 2008.

Kösternberger, Andreas J. God, Marriage, and Family: Rebuilding the Biblical Foundation. Wheaton, Ill.: Crossway Books, 2004.

Marsman, Hennie J. Women in Ugarit and Israel: Their Social and Religious Position in the Context of the Ancient Near East. Leiden: Brill, 2003.

Masenya, Madipoane. "Killed by Aids and Buried by Religion: African Female Bodies in Crisis." Old Testament Essays 19/2 (2006): 486-499.

Metuh, Emefie Ikenga. Comparative Studies of African Religions. Enugu: SNAAP Press, 1999.

Miscall, Peter D. 1 Samuel: A Literary Reading. Bloomington: Indiana University Press, 1986.

Modo, Innocent V.O. "A Cultural Panacea to the Problem of 'Malelessness' in Igbo Land of Nigeria: The Study of Eze-Chiman Clan.” African Anthropology 5/2 (1999): 198-205.

Moyo, Chiropfadzo. "A Karanga Perspective on Fertility and Barrenness as Blessing and Curse in 1 Samuel 1:1-2:10.” D.Th. Thesis Stellenbosh University, 2006.

Moyo, Themba. "Naming Practices in Colonial and Post-Colonial Malawi." Inkanyiso 4/1 (2012): 10-16.

Nkomazana, Fidelis. "Polygamy and Women within the Cultural Context in Botswana." Scriptura 92 (2006): 265-277.

Odukoya, Bimbo. Marriages: Real People, Real Problems, Wise Counsel. Lagos: Grace Spring Africa Publishers, 2006.

Okeke Hilary O. "Population, Marriage, and Family in Nigeria." Pages 57-76 in Marriage and Family in Nigeria. Edited by Benedict E. Etafo and Hilary O. Okeke. Onitsha: Rex Charles \& Patrick Ltd, 1993.

Reiss, Moshe. “Jephtha's Daughter.” Jewish Biblical Quaterly 37/1 (2009): 57-63. 
Riley, Bove and Claudia Valeggia. "Polygyny and Women's Health in Sub-Saharan Africa." Social Science and Medicine 68/1 (2009): 21-29.

Scharbert, Josef \& Hentschel, Georg, Rut, 1 Samuel. Die Neue Echter Bibel: Commentar Zum Alten Testament Mit Der Einheitsübersetzung. Würzburg: Echter Verlag, 1994.

Smith, Henry Preserved. A Critical and Exegetical Commentary on the Book of Samuel. Edinburgh: T\&T Clark, 1961.

Shorter, Aylward. African Culture and the Christian Church. London: Geoffrey Chapman, 1973.

Tsumura, David T. The First Book of Samuel. The New International Commentary on the Old Testament. Grand Rapids, Mich.: Eerdmans, 2007.

Uchendu, Victor. The Igbo of the Southeast Nigeria. London: Holt, Rinehart and Winston, 1965.

United Nations. Universal Declaration of Human Rights, December 10, 1948. http://www.un.org/en/universal-declaration-human-rights/index.html (accessed on 04.07.2015).

Uwalaka, Emmanuel. Towards a Sustainable Happy Marriage: A Functional Appraoch. Owerri: Danstarling, 2008.

VanGemeren, Willem A., ed. New International Dictionary of Old Testament Theology and Exegesis. Grand Rapids: Zondervan, 1997.

Van Zyl, Danie. "Hannah's Share, Once More 1 Samuel 1:5." Old Testament Essays 6/3 (1993): 364-339.

Waters, Brent. Ethics and Technology: Towards a Theology of Procreative Stewardship. Wiltshire: Longman, 2001.

Welch, Charles E. and Paul C. Glick. "The Incidence of Polygamy in Contemporary Africa: A Research Note." Journal of Marriage and Family 43/1 (1981): 191193.

West, Gerald O. "Contextuality." Pages 400-414 in The Blackwell Companion of the Bible and Culture. Edited by John F. A. Sawyer. Malden, Mass.: Blackwell Publishing, 2006.

Dr. Alexander Izuchukwu Abasili, Biblical Studies, Catholic University, Leuven, Belgium. Dorfstraße 2, D-93099 Mötzing, Germany. Email: alexabasili@yahoo.com. 